\title{
ORGANIZATION AND COSTS OF REPURCHASING, TRANSPORTATION, WAREHOUSING AND STORAGE OF RASPBERRY FRUIT ${ }^{1}$
}

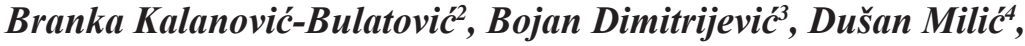 \\ Zoran Milovančevićs
}

\section{Summary}

Due to its characteristic, apart from nutritive and medical significance, raspberry is particularly important for our country in social and economic terms, since its export attracts foreign currency inflow.

Since the quality of raspberry decreases rapidly after picking, it is utterly important that the whole process, from picking to cold storage of fruit, should be rationally organized, thus finally reducing the costs and increasing the production value. For these reasons precisely the research deals with organization of the entire process, from repurchase to cold storage of raspberry fruits, as well as the analysis of pertaining costs.

Necessary information for the preparation of the paper has been obtained from cold storage plants engaged in raspberry storage and preservation.

Necessary information has been gathered using several methods, viz: observation, interview and content analysis methods. Furthermore, analysis, comparison and calculation methods have also been used in the preparation of the paper.

The raspberry fruit repurchase, transport and storage costs range from 1,6 to 1,8 EUR per $\mathrm{kg}$, exclusive of storage (store-housing). To this one should add store-housing costs ranging from 0,009 to 0,013 EUR per $\mathrm{kg}$ on a monthly basis.

1 Paper is a part of research within the projects: Sustainable agriculture and rural development in the function of accomplishing strategic objectives of the Republic of Serbia in the Danube region (No. III 46006), and Rural Labor Market and Rural Economy of Serbia - Income Diversification and Poverty Reduction (ON 179028), financed by the Ministry of Education, Science and Technological Development of the Republic of Serbia. Project period: 2011-2014.

2 Branka Kalanović-Bulatović, Ph.D. University of Belgrade, Faculty of Agriculture, Nemanjina street no. 6, 11080 Belgrade, Republic of Serbia, Phone: + 381112615315 ext. 495, E-mail: brankal@agrif.bg.ac.rs

3 Bojan Dimitrijević, Ph.D., University of Belgrade, Faculty of Agriculture, Nemanjina street no. 6, 11080 Belgrade, Republic of Serbia, Phone:+ 381642248 076, E-mail: bojandi@agrif.bg.ac.rs

4 Dušan Milić, Ph.D., University of Novi Sad, Faculty of Agriculture, D. Obradović square no. 8, 21000 Novi Sad, + 381635575 82, e-mail address: milic@polj.uns.ac.rs

5 Zoran Milovančević, MSc, Kamenička street no. 10, 34310 Topola, Republic of Serbia, Phone:+ 381636477 83, E-mail: zoranmilovancevic@gmail.com

EP 2015 (62) 4 (1017-1030) 
Modern organization of production and communication between producers, repurchasers, processors and exporters is essential in order to decrease fluctuations in repurchase and sales price of fresh raspberry and its products and the improvement of overall financial effect of all links within the chain of this economy activity. Cold storage plants, even if of minor capacities, are beneficial not only for the immediate participants in the producer-buyer chain, but it also makes an important stimulating factor for rural development and economy of the country.

Key words: organization, costs, storage, freezing, raspberry

JEL: $L 230, Q 13$

\section{Introduction}

Raspberry is one of the most important agricultural products, since it provides huge foreign currency income and a leading position of our country in the list of the most important producers and exporters of this fruit in the world. We can say that raspberry falls within most significant products, with regard both to agriculture and Serbian economy in general. Namely, in recent years, annual production of raspberries has been around $80.000 \mathrm{t}$ which makes approximately $5.5 \%$ of the total fruit production. Over $90 \%$ of produced raspberry is frozen and exported and the rest is sold as fresh or processed in other products. Serbia participates with around $25 \%$ in the world raspberry production and exports mostly frozen and very rarely chilled raspberries (Dimitrijević, 2009). Thus crediting around 120 million EUR to the payment balance of our country (Kljajić, 2012). Additional economic importance of raspberries is reflected in the "extremely high level of marketing and competitiveness in the EU market, where demand for frozen raspberries produced in our geographical and environmental conditions is increasing." The largest quantities of raspberry from our country is exported to Germany, France, Belgium, Austria, Sweden, the UK and the Netherlands (Kljajić, 2014).

Serbia has numerous favourable conditions for the improvement of raspberry production and processing. We can draw such a conclusion if taken into account natural potential and certain infrastructural facilities (processing capacities). Such potential should be utilized properly.

Raspberry is among the most labour-demanding fruit products, since it requires much more labour than other fruits, in almost all stages of the production process, especially during picking. A significant number of people are also engaged in the fruit processing and transport. It is estimated that around 200.000 people work on raspberry growing in Serbia, including seasonal workers. In Serbia, production of raspberries is predominant in small family plantations sized $0.1-0.3$ hectares, and in mountainous areas where 40,000-50,000 households in the plantations sized between 14,000 and 16,000 hectares participate in production.

Raspberry production may provide relatively high value of production, income and profit per unit of invested capital and manual labor. 
We can say that increase in surface and yield, as well as raspberry processing and sale, could affect decrease in unemployment and rural poverty, thus increasing income of individual agricultural households and development of rural regions. In a word, raspberry production may directly and indirectly affect overall economic development of our country.

In order to keep our current position in raspberry production and export all over the world, we must constantly insist on the improvement of quality of fresh raspberry and finished products and reduction in the number of mediators in the sales chain.

Apart from the abovementioned, modern organization of production and communication between producers, buyers, processors and exporters is essential in order to achieve satisfactory economic results. This may reduce fluctuations in buying and selling prices of fresh raspberry and its products and improve overall financial effect of all links within the chain of this economy activity (Dimitrijević, Ceranić, 2011).

Taking into account everything mentioned above, the aim of the research was to determine the costs of repurchasing, transportation, warehousing and storage of raspberry fruit, as well as to analyse the organization of frozen raspberry production process.

\section{Methodology and data sources}

Information for this study was collected during the raspberry picking season, June and July 2014, at cold storage plants where raspberries were stored and preserved, located in Municipality Arilje, one of the most important raspberry-growing territories. The whole process was observed, from raspberry picking, transport, repurchase, delivery, storage, preservation, to the shipment of frozen raspberries to the buyer. Some data and information were gathered through interviews with responsible persons who actively participated in the entire chain. Internal documentation of the business system dealing with the above mentioned activities was also analyzed. Therefore, methods used to collect necessary data and information were: observation, interview and content analysis. Apart from this, analysis, comparison and calculation methods were used as well.

\section{Research Results}

After picking, fruit has to be transported as soon as possible to the end user or processing facility. In case of raspberry, it is usually a cold storage plant. Recommendation is to refrigerate picked fruit the same day. Quick refrigerating of fruits after picking slows down ripening process and minimizes occurrence of some physiological diseases (Nikolić, Milivojević, 2010). It is estimated that Serbia loses 30-40\% of its products in different stages after picking.

It is utterly important that the whole process, from picking to cold storage of fruit, should be rationally organized, thus finally reducing the costs and increasing the production value. For these reasons precisely the research deals with organization of the entire process, from repurchase to cold storage of raspberry fruits, as well as the analysis of pertaining costs. 


\section{Basic Task of Warehouse and Storage of Fruit in Cold Storage Plants}

Ever since ancient times, people have strived to keep nutrition food fresh for as long as possible. Thereby, fresh fruit is offered year round. Processing also preserves quality and value of product while at the same time, when possible, value is added through selection and technology, making fruit seem more attractive or valuable to the consumer.

Modern fruit growing is therefore unimaginable if adequate capacities enabling the afterpicking fruit preservation, for shorter or longer period of time, are lacking. The length of this period depends on fruit species, technical properties of the storage and possibility of control of conditions inside the warehouse (temperature, relative humidity, concentration of oxygen and carbon dioxide, removal of ethylene, etc.) (Janković, 2002).

\section{Importance of Cold Storage Plants}

„Freezing is one of the oldest and most widely used methods of food preservation, which allows preservation of taste, texture, and nutritional value in foods better than any other method" (FAO, 2005). The freezing process is a combination of the beneficial effects of low temperatures at which microorganisms cannot grow, chemical reactions are reduced, and cellular metabolic reactions are delayed (Delgado, Sun, 2001). According to some data Romans kept natural ice and transported it in cars covered with hay (Ivanović, 2009). Today, even though there are other solutions, the best way for preservation of fresh fruit and keeping its freshness and aroma is in cold storage plants. Due to the invention of cold storage plants we now have fruits in markets year round. It is important to note that the quality of fruit stored in cold storage plants cannot be improved, only the existing quality can be maintained. For this reason, during the planning of production, it is necessary to take into account the choice of varieties of raspberries. Therefore, the strategy of raspberry market development, among others, should be based on the cultivation of raspberries that are suitable for storage over a longer period of time (Kljajić et al., 2013). Refrigerating capacities in Serbia today are around 483.000 t (Business Unit for Fruit and Vegetables, Belgrade, 2008). Nowadays there are different types of cold storage plants used for fruit, and basic differences are on the level of technical solutions and equipment used in them.

\section{Organization of Frozen Raspberry Production Process}

Frozen raspberry production is a complex process. It encompassed a series of activities applied from the acceptance of fresh raspberry at a cold storage plant to production of certain products of frozen raspberries. Organization of the production process of frozen raspberries is presented in process flow diagram (Diagram 1).

Acceptance - Producers transport fresh raspberry by their own vehicles in fruit crates that are provided by a purchaser. Control, i.e. quality assessment, is carried out at acceptance, samples are taken from each manufacturer and sent to authorized external laboratories to verify the content of pesticide residues, heavy metals and present 
microorganisms. Then, raspberry is unloaded, classified, weighed and piled on a pallet. Fresh raspberries are classified into two classes: First class and Second class. Up to 80 $\mathrm{t}$ raspberries can be placed in a cold storage plant daily.

Diagram 1. The process of production of frozen raspberries

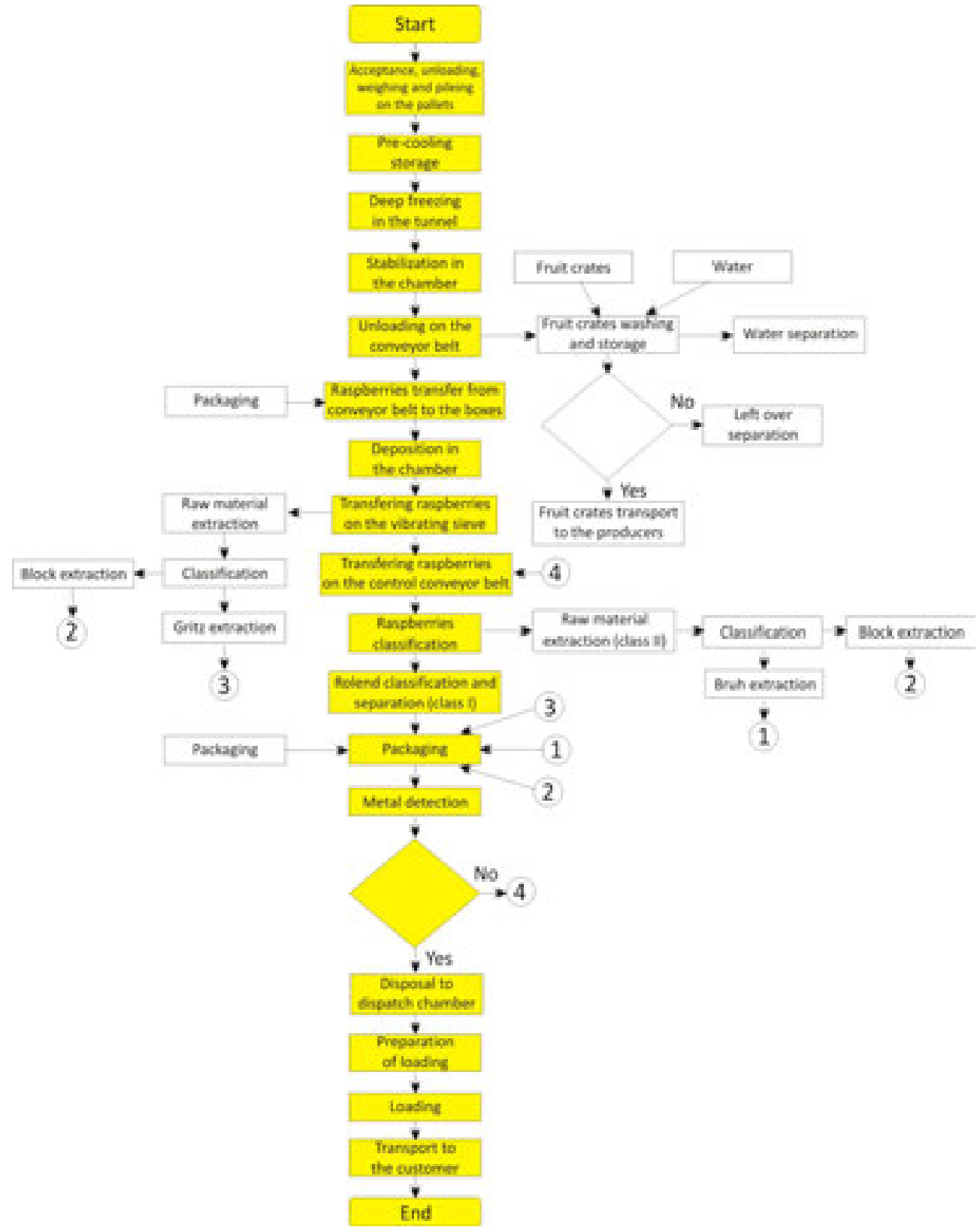

Source: Developed by authors using the observation, interview and content analysis methods 
Pre-cooling Storage - Goods are placed on pallets and stored in pre-cooling $\left(0^{\circ} \mathrm{C}-2\right.$ $\left.{ }^{\circ} \mathrm{C}\right)$ where auto control is performed (method of loading pallets in a pre-cooling, air temperature and time of pre-cooling). Storage capacity is 1,000 tons of raspberries, in two cold storage plants with capacity of $500 \mathrm{t}$ each.

Deep Freezing in the Tunnel - Pre-cooled raspberries are deep frozen in tunnels (from -25 to $-30^{\circ} \mathrm{C}$ ). Auto control is performed in the tunnel (air temperature, turning -on and -off time, raspberry temperature). Up to 70 tons of raspberries a day can be frozen in the tunnels, depending on the tunnel capacity.

Stabilization in the Chamber - Deep frozen raspberry from the tunnel is placed in the chamber $\left(-18^{\circ} \mathrm{C}\right)$ for stabilization. Auto control is performed in the chamber (date and time of the beginning of stabilization).

Unloading - After stabilization in the chamber raspberry is delivered for processing ( 0 ${ }^{\circ} \mathrm{C}-5^{\circ} \mathrm{C}$ ), manually placed on a conveyor belt where major impurities are eliminated, and then packed into bags and boxes that were previously stored in packaging storage. Auto control is performed on the conveyor belt; (raspberry temperature, quality and quantity of unloaded fruit). 90-100 $\mathrm{t}$ of raspberries can be transferred daily in cold storage plant. At this stage 10 and $12 \mathrm{~kg}$ five-layer cardboard boxes are used, filled with bags of $10 \mathrm{~kg}$ and $12 \mathrm{~kg}$. $(5,10$ and $12 \mathrm{~kg}$, in which $0.3,0.75,1,2,5,10$ and 12 kg bags are put).

Fruit Crate Washing and Storage - Empty fruit crates are transferred on a special conveyor belt to a washing machine and then stored in a warehouse for washed fruit crates wherefrom raspberry producers can take them for new fruit picking. Analyzed company has 80000 fruit crates of its own. Up to 120000 fruit crates can be daily washed on the conveyor belt.

Deposition in the Chamber - Raspberry in boxes is packed in so called ram pallets and then returned to the chamber at temperature of $-22^{\circ} \mathrm{C}$.

Transferring Raspberries on a Vibrating Sieve - Boxes with deep frozen raspberries are transported from the chamber to the processing plant for further processing where they are manually unloaded in a vibrating sieve (auto control- amount of raspberries on vibrating sieve) where whole fruits are separated and sent to control conveyor belt, and the rest of the sieved raw material is collected in a separate, secondary packaging.

Raspberry Classification on the Control Conveyor Belt - Raspberries are manually selected on the control conveyor belt.

Rolend Classification and Separation (class I) - Raspberry is classified, (workers manually separate class II to a separate narrow conveyor belt) Class I i.e. Rolend is left on the conveyor belt.

Packaging - Rolend is packaged in separate primary packaging.

Metal Detection - Raspberry goes through a metal detector to check whether there is 
any metal in the product. If so, raspberry goes back to the control conveyor belt, and the packaging in which it was packed passes separately through the metal detector to determine whether metal might be found in the package itself.

Mouldy, misshapen, quirky, broken, overripe and green fruits that are packed into bags and boxes are placed as secondary products in the chamber and are separated in a special part of the inspection conveyor belt. Auto control of packaging is performed (number and appearance of bags, quality of welds on bags, net and gross weight, date)

Disposal to Dispatch Chamber - After the metal detector, boxes with Roland are placed on pallets, labelled, stretch wrapped and returned to dispatch chamber.

Preparation of Loading, Loading, Transport to the Customer - Raspberry from the chamber is transported to the loading ramp, and then packed in refrigerated trucks to be transported to the customer. Temperature control is performed before pallet boxes are loaded into trucks and the boxes are visually checked for any signs of damage. Auto control is performed also during transportation to the customer (proper operation of cooling devices and temperature in the truck).

Raw Materials Extraction - Semi-product which remained in secondary raw material boxes after separation on a vibrating sieve is returned again to the inspection conveyor belt where Block and the mass for Gritz are separated, which make finished products when classified in such a manner. Gritz control is performed (vegetative and other impurities, mould, dry substance, dust). Secondary raw material is packed into bags and boxes, it passes through a metal detector, then is piled on a pallet and labelled, stretch wrapped and placed in the dispatch chamber, and finally loaded into refrigerated trucks $\left(-18^{\circ} \mathrm{C}\right)$ and transported to the destination of the customer.

Raw Materials Extraction (Class II) - After separating Rolend, a semi-product remains on the inspection conveyor belt in a box with recycled secondary raw material, where after it is transferred back to the conveyor belt where Bruh and Block are separated, and classified to be packed into bags and boxes, it passes through a metal detector, then it is piled on pallets, labelled and stretch wrapped, placed in the chamber until loaded into refrigerated trucks and transported to the customer.

\section{Raspberry Repurchase, Transport, Warehouse and Storage Costs}

On the world market there is still plenty of room for the placement of fresh and processed raspberries. However, it is necessary to constantly perform market research, because in this way the company provides the information basis for production planning (Kalanović et al., 2003). This is one of the key factors for the successful organization of production and overall business success. However, the aggravating circumstance is the fact that the "economic conditions in raspberry production changes from year to year, as well as the repurchase price of fresh raspberries, which often leads to dissatisfaction among producers and even processors (cold storage plants)" (Veljković et al., 2006). This situation exist in our country for a long period of time. However, despite this, some 
experts on the basis of their research concluded that "for fruit companies or farms is recommended the inclusion of the construction of cold storage in development policy, even assuming that such investment is largely financed by loans from commercial banks" (Ivanović et al., 2009). The investment process includes financial investment in the present in order to achieve economic benefits or effects in the future (Milic, Sredojević, 2008). It is always imposed a question of costs related to the repurchase, transport, warehouse and storage of raspberries, as well as the factors that affect them. The following part of the paper is an attempt to answer to these questions.

Raspberry original means raspberry fruit in the condition as purchased from the producer and finished products are the products after raspberry original selection.

Capacity of the cold storage plant -2 chambers $(1000+1050 \mathrm{t})$. What is specific about raspberry storage is the fact that products are stored at the refrigerating temperature of minimum -18 do -21 degree. Goods are contained in a cardboard five-ply packaging $(\mathrm{k}-240)$ and boxes are arranged on industrial palettes $(1,000 \times 1,200)$ or cabinets specially made for that purpose and so arranged into chambers.

Storage costs depend on the price of electrical energy and fullness of the capacity of the storage chamber (the fuller the chamber, the less frequently we switch on the refrigerating, making the costs lower). Fresh goods entering the cold storage plant have approximately $3-4 \% \mathrm{kal}$, and costs of electrical energy for freezing range from 1.1 to $2.8 \mathrm{EUR}$ cent $/ \mathrm{kg}$.

We should point out that raspberry fruit storage has a number of options and combinations which are mostly subject to agreement between interested parties and the relevant circumstances (raspberry producer and cold storage plant operator). Most frequently raspberry fruits may be given to cold storage plants:

1. for repurchase,

2. for servicing refrigeration and storage, or

3. for servicing storage only (storehousing)

1.In the first case, raspberry fruit is repurchased by the cold storage plant operator and the producer is paid money for raspberry and has no influence or any connection whatsoever with further processing. In this case all further costs of handling are borne by the cold storage plant operator.

2. In the second case there are two options, raspberry fruits may be refrigerated without selection, while the other option includes selection, which entails additional costs. Handling costs - with or without selection on a monthly level.

Costs of acceptance, delivery, cooling, packing into boxes and bags and refrigeration (without selection) is 10 EUR cent $/ \mathrm{kg}$ if handling is done for own needs. However, if it is done as a service activity, costs are twice as much (20 EUR cent $/ \mathrm{kg}$ ).

In 8 hours of work with 13 employees handling costs (taking fruit out of the wooden box) are $9-10$ EUR cent $/ \mathrm{kg}$. 
3. In the third case frozen raspberry is delivered to a cold storage plant, sent to chambers and kept at a regulated temperature. Average monthly costs of preservation are approximately 3 EUR cent $/ \mathrm{kg}$.

Accordingly, costs of raspberry cold storage and handling are relatively high (Table 1).

As can be seen from Table 1, the second largest share in the cost structure, (after the price of raw materials - raspberry), belongs to labor costs of raspberries buyers, which essentially represent intermediaries between small producers and processing facilities or customers. They supplied $75 \%$ of fresh fruit cold storage in Serbia, of which charge for their services and thus increase the cost of the end product (Radosavljević, 2008). In addition, it reduces the possibility of control of the origin of raspberry and increases the likelihood of various speculations. The exclusion of raspberry re-purchasers from the supply chain, as intermediaries, through various forms of integration of other supply chain participants, would increase the control of the origin of raspberry and reduce costs. Besides, any working arrangement that reduces handling will lead to lower costs and will assist in reducing quality losses (El-Ramady et al., 2015).

Table 1. Costs of raspberry reception, freezing and storehousing in a cold storage plant

\begin{tabular}{|c|c|c|c|c|}
\hline \multirow[t]{2}{*}{ Type of costs } & \multirow[t]{2}{*}{ Amount } & \multirow{2}{*}{$\begin{array}{l}\text { Unit of } \\
\text { measure }\end{array}$} & \multicolumn{2}{|c|}{$\begin{array}{c}\text { Amount of costs } \\
\text { per } 1 \mathrm{~kg} \text { of raspberry }\end{array}$} \\
\hline & & & RSD & EUR $^{6}$ \\
\hline Raw material price (raspberry) ${ }^{1}$ & 170 & $\mathrm{RSD} / \mathrm{kg}$ & 170 & 1.476 \\
\hline Raspberry re-purchasers' fee & $5-15$ & $\mathrm{RSD} / \mathrm{kg}$ & $5-15$ & $0.043-0.130$ \\
\hline $\begin{array}{l}\text { Raw material transport material } \\
\text { (raspberry) }^{2}\end{array}$ & $1-7$ & $\mathrm{RSD} / \mathrm{kg}$ & $1-7$ & $0.009-0.061$ \\
\hline Employees' fee & $2-3$ & $\mathrm{RSD} / \mathrm{kg}$ & $2-3$ & $0.017-0.026$ \\
\hline Seasonal workers' fee & $2-4$ & $\mathrm{RSD} / \mathrm{kg}$ & $2-4$ & $0.017-0.035$ \\
\hline Electrical energy (freezing) & $2.5-3$ & $\mathrm{RSD} / \mathrm{kg}$ & $2.5-3$ & $0.022-0.026$ \\
\hline Raspberry freezing kalo ${ }^{3}$ & $2-4$ & $\%$ & & \\
\hline a) Packaging - box K-240 & 36 & $\mathrm{RSD} / \mathrm{pc}$ & $2.4-3.6$ & $0.021-0.031$ \\
\hline b) Packaging - bag ${ }^{5}$ & 6 & $\mathrm{RSD} / \mathrm{pc}$ & $0.4-0.6$ & $0.003-0.005$ \\
\hline Wooden pallets $(1,000 \times 1,200)^{6}$ & 700 & $\mathrm{RSD} / \mathrm{pc}$ & $\mathrm{x} \rightarrow 0$ & $\mathrm{x} \rightarrow 0$ \\
\hline Total: & & $\mathrm{RSD} / \mathrm{kg}$ & $185.3-206.2$ & $1.608-1.790$ \\
\hline Raspberry storehousing/1 month ${ }^{7}$ & $1-1.50$ & $\mathrm{RSD} / \mathrm{kg}$ & $1-1.50$ & $0.009-0.013$ \\
\hline
\end{tabular}

Source: Work of authors, based on the information obtained from the cold storage plants in Arilje

${ }^{1}$ Repurchase price of raspberry in the picking season - June-July 2014. This is the price at the repurchase point distant from the cold storage plant.

${ }^{2}$ These are average costs of raspberry transport to the cold storage plant. There are two options of such transport. First, when the cold storage plant organizes transport

$6 \quad 115.21$ RSD for 1 EUR-middle exchange rate of the National Bank of Serbia as at July 1, 2014

EP 2015 (62) 4 (1017-1030) 
at its own cost, from the repurchase point to the cold storage plant. Then the costs of transport are $1-1.5$ RSD per kilogram. If raspberry producers transport the picked raspberry by their own vehicles to the cold storage plant they get additional 5 to 7 RSD per kilogram. Therefore, at the cold storage plant itself the repurchase price was $170+5$ to 7 RSD. Furthermore, it is very hard to determine precise amount of all costs.

${ }^{3}$ Freezing kalo is calculated by technologists at the cold storage plant. This is done by recording the weight of a few pallets of fresh raspberry before they are put into a tunnel. After freezing in the tunnel they are re-measured and the difference in weight is recorded. This value is actually the freezing kalo. There is also processing kalo which is recorded upon completing the total processing of goods. Processing kalo is around $1 \%$.

${ }^{4}$ A box may contain 10 to $15 \mathrm{~kg}$ of raspberry (Rolend 10-12 kg, Bruh 11-13 kg, Gritz $14-15 \mathrm{~kg})$.

${ }^{5}$ The said bag may contain 10 to $15 \mathrm{~kg}$ of raspberry, depending on the quality. In case of variety Rolend, the weight is $10-12 \mathrm{~kg}$, Bruh $12-13 \mathrm{~kg}$ and Gritz $14-15 \mathrm{~kg}$.

670 to 80 boxes, i.e. 700 to $1200 \mathrm{~kg}$ of raspberry may be packed on a $1,000 \times 1,200$ $\mathrm{mm}$ pallet. Pallets are replaced approximately at 5 years, which depends on expertise of workers and on the storage mode. In general, they should be plastic, but most cost storage plants used wooden ones, due to reduced costs.

${ }^{7}$ In practice, the price of store housing is most frequently calculated by month, but it can also be calculated by day. Recalculation is performed proportionally to the number of preservation days.

The cost of energy used for freezing process and storage of raspberry fruits is also significant. In many developing countries the cost of energy for industrial use is relatively high, highlighting the need for governments in developing countries to consider establishing lower energy tariffs in order to promote agro-food processing industries such as freezing (FAO, 2005). As for cost distribution, the freezing process and storage in terms of energy consumption constitute approximately 10 percent of the total cost of production (Person, Lohndal, 1993).

But, after all, the main cost of a cold storage facility is due to the construction of the building, preparation of the site, and provision of the services. In developed countries the freezing of foods represents a major industry, but in developing countries it is hardly developed. The frozen foods industry is considered expensive, mainly due to the high initial investment cost for the equipment (FAO, 2005). Public cold stores also provide service for small-scale operations and are relatively less costly than private ones.

The repair cost for cold storage facilities should be also considered. For example, the U.S. Department of Agriculture (USDA), in the long-run, recommends an expected repair cost for new freezers of 2 percent of the purchase price per year, but for used 
freezers, this rate may be higher (Johnston et al., 1994).

However, design and construction costs of a cold storage facilities and the costs of storage of raspberry fruits in them could be substantially reduced. This can be achieved if the family farms, which perform almost the entire raspberry production in our country, join themselves. In addition to that, there could be other benefits as well.

It could be possible to standardize the technology and quality of stored products, to ensure the possibility of licensing cold storage facilities as a precondition for the introduction of warehouse receipts as collateral for loans to producers, and finally to carry out collective strategic market research and the introduction of "brand name" products (Tratnik et al., 2006). Without doubt, all of this could lead to a greater profitability, sustainability, and competitive advantages for all participants in postharvest supply chain of raspberry fruits.

\section{Conclusion}

Due to its properties, apart from nutritive and medical significance, raspberry is particularly important for our country in social and economic terms, since the export thereof attracts inflow of foreign currency. However, raspberry is extremely sensitive to external influence. Accordingly, to ensure continuous and high quality offer of fresh and processed raspberry fruits throughout the year, both on domestic and foreign market, it is essential to preserve fruit quality for as long as possible. Modern fruit growing is therefore unimaginable if adequate capacities enabling the after-picking fruit preservation are lacking. Although there are numerous modes available with regard to the matter, freezing has so far been one of the best and most commonly used one. The quality of raspberry fruit after cold storage plants depend on: the variety, technical properties of the cold storage plant. Considering the fact that the quality of raspberry rapidly decreases after picking, the knowledge and the use of modern technology of the entire process, from picking to storage of fruit in cold storage plants, especially rational organization and realization, is of utmost importance, which ultimately reflects on the reduction of costs.

The results of this research show that the raspberry fruit repurchase, transport and storage costs range from 185.3 to 206.2 RSD (from 1,6 to 1,8 EUR) per kilogram, exclusive of storage (store-housing). To this one should add store-housing costs ranging from 1 to 1.50 RSD, (from 0,009 to 0,013 EUR) per kilogram on a monthly basis.

Therefore, modern organization of production and communication between producers, re-purchasers, processors and exporters is essential in order to decrease fluctuations in repurchase and sales price of fresh raspberry and its products and the improvement of overall financial effect of all links within the chain of this economy activity.

Considering the above, we may conclude that cold storage plants, even if of minor capacities, are preferential not only for the immediate participants in the producer buyer chain, but it also makes an important stimulating factor for rural development 
and economy of the country in general.

\section{References}

1. Delgado, A. E., Sun, D. W. (2001): Heat and mass transfer models for predicting freezing processes - a review, Journal of Food Engineering, Vol. 47, No. 3, pp. 157-174.

2. Dimitrijević, B. (2009): Organizacioni model kooperative proizvođača malina (Organizational Model of Raspberry Producers Cooperative), MSc thesis, Faculty of Agriculture, University of Belgrade, Belgrade, Republic of Serbia.

3. Dimitrijević, B., Ceranić, S. (2011): Razvoj proizvodnje maline u funkciji smanjenja ruralnog siromaštva u republici Srbiji (Development of Raspberry Production Aimed to Decrease Rural Population in the Republic of Serbia), Ekonomika poljoprivrede (Agricultural Economics), Belgrade, Republic of Serbia Vol. 58, No. 2, pp. 163-174.

4. El-Ramady, R. H., Domokos-Szabolcsy, É., Abdalla, A. N., Taha, S. H., Fári, M. (2015): Postharvest Management of Fruits and Vegetables Storage, Sustainable Agriculture, Springer, Vol. 15, pp. 65-152.

5. Food and Agriculture Organization of the United Nations, (2005): Freezing of fruits and vegetables: an agri-business alternative for rural and semi-rural areas, Rome, Italy.

6. Internal documentation of Business Community for Fruit and Vegetable, Belgrade, 2008.

7. Internal documentation of Cold storage plants, Municipality of Arilje, June and July 2014.

8. Ivanović, L, Milić, D, Ivanović, S. (2009): Investiranje u hladnjače za voće kao oblik razvojne politike preduzeća, Ekonomika poljoprivrede, Beograd, Republic of Serbia, Vol. 56, No. 4, pp. 589-599.

9. Ivanović, L. (2009): Ocena ekonomskih efekata u izgradnju kontejnerske hladnjače za čuvanje jabuke (Evaluation of Economic Effects in Constructing Container Cold Storage Plant for Apple Preservation), MSc thesis, Faculty of Agriculture, University of Novi Sad, Novi Sad, Republic of Serbia.

10.Janković, M. (2002): Tehnologija hlađenja (Cooling Technology), General part, Faculty of Agriculture, Belgrade, Republic of Serbia.

11.Johnston, W. A., Nicholson, F. J., Roger, A., Stroud, G. D. (1994): Freezing and refrigerated storage in fisheries. FAO, Fisheries technical paper - 340.

12.Kalanović-Bulatović,B., Rajić,Z., Ralević,N.,Dimitrijević,B.(2003): Prognoziranje proizvodnje maline (Raspberry Production Forecast), The $1^{\text {st }}$ Symposium on Raspberry of Serbia and Montenegro with International Participation, Extracts of Notices, Institute for Research in Agriculture Serbia, Scientific Fruit Association of Serbia and Montenegro, pp. 144-145.

13.Kljajić, N. (2012): Ekonomska efikasnost investicija u različitim uslovima proizvodnje maline, Doktorska disertacija, Poljoprivredni fakultet, Univerzitet u Novom Sadu, Novi Sad, Republika Srbija. 
14.Kljajić, N. (2014): Efikasnost investicija u proizvodnji maline, Monografija, Institut za ekonomiku poljoprivrede, Beograd, Republika Srbija.

15.Kljajić, N., Vuković, P., Arsić, S. (2013): Tendencies related to the production of raspberries in the Republic of Serbia, Economics of Agriculture, Belgrade, Republic of Serbia, Vol. 60, No 1, pp. 39-48.

16. Milić, D., Sredojević, Z. (2008): Mogućnosti procene rizika poslovanja poljoprivrednog preduzeća, PTEP-Časopis za procesnu tehniku i energetiku u poljoprivredi, Novi Sad, Republika Srbija, Vol.12, No. 1-2, pp. 53-56.

17.Nikolić, M., Milivojević, J. (2010): Jagodaste voćke - tehnologija gajenja (Berry Fruits - Growing Technology), Scientific Fruit Growing Association of Serbia, Čačak, pp. 249-250.

18.Persson, P. O., Lohndal, G. (1993): Freezing Technology, Frozen Food Technology (Mallett CP ed.), Chapman and Hall, London, UK.

19. Radosavljevic Katica (2008): The market chain of fruit production in Serbia: A case study of raspberry and sour cherry cultivation, Economic annals, National Library of Serbia, Vol. 53, No. 177, pp. 103-121.

20.Tratnik, M., Grgić, I., Pliestić, S. (2006): Organizacijsko-ekonomski koncept zadružne mreže hladnjača za voće i povrće s obiteljskih gospodarstava u Hrvatskoj, Aktualni zadaci mehanizacije poljoprivrede, HINUS, Zagreb, Republika Hrvatska, pp. 457-466.

21. Veljković, B., Petrović, S., Leposavić, A., Glišić, I. (2006): Profitabilnost proizvodnje maline na području Srbije, Ekonomika poljoprivrede (Agricultural Economics), Belgrade, Republic of Serbia, Vol. 53, No 4, pp. 1013-1022. 


\title{
ORANIZACIJA I TROŠKOVI OTKUPA, TRANSPORTA, SKLADIŠTENJA I ČUVANJA PLODOVA MALINE
}

\author{
Branka Kalanović-Bulatović7 ${ }^{7}$,Bojan Dimitrijevic ${ }^{8}$, Dušan Milić ${ }^{9}$, \\ Zoran Milovančević ${ }^{10}$
}

\begin{abstract}
Sažetak
Malina, zahvaljujući osobina kojima se odlikuje, pored nutritivnog i zdravstvenog, kroz devizni priliv koji se ostvaruje njenim izvozom, za našu zemlju ima i naročit društveni i ekonomski značaj.

S obzirom na činjenicu da kvalitet maline rapidno opada nakon berbe, od izuzetnog je značaja da čitav proces od berbe do skladištenja voća u hladnjačama bude racionalno organizovan, što bi u krajnjoj liniji trebalo da se odrazi i na smanjenje troškova $i$ povećanje vrednosti proizvodnje. Iz tih razloga je predmet istraživanja u radu upravo organizacija čitavog procesa, od otkupa do čuvanja plodova malina u hladnjačama, kao i analiza troškova koji nastaju prilikom realizacije istog.

Podaci za izradu rada dobijeni su iz hladnjača koje se bave skladištenjem i čuvanjem maline. Za prikupljanje podataka potrebnih za izradu rada korišćeno je nekoliko metoda i to: metod posmatranja, metod intrvjua i metod analize sadržaja. Pored njih, u izradi rada, korišćene su još i metod analize, metod poređenja i metod kalkulacije.

Rezultati ovog istraživanja pokazuju da se troškovi otkupa, transporta i skladištenja plodova maline kreću se od od 1,6 do 1,8 evra po kg, bez čuvanja. Na to se dodaju troškovi lagerovanja koji se kreću od 0,009 do 0,013 evra po kg na mesečnom nivou.

Savremena organizacija proizvodnje, kao i komunikacija između proizvođača, otkupljivača, prerađivača i izvoznika, od presudnog je značaja za smanjenje fluktuacije otkupnih i prodajnih cena sveže maline $i$ njenih proizvoda $i$ poboljšanje opšteg finansijskog efekta svih karika koje čine lanac ove privredne aktivnosti.

Hladnjače za čuvanje maline, čak $i$ one manjeg kapaciteta, nisu od koristi samo neposrednim učesnicima u lancu od proizvođača do kupca, već predstavljaju i značajan faktor podsticanja ruralnog razvoja i ekonomije zemlje u celini.
\end{abstract}

Ključne reči: organizacija, troškovi, skladištenje, zamrzavanje, malina

7 Dr Branka Kalanović-Bulatović, Poljoprivredni fakultet Univerziteta u Beogradu, Nemanjina ulica br. 6, 11080 Beograd, Telefon: + 381112615315 lokal 495, E-mail: brankal@agrif.bg.ac.rs

8 Dr Bojan Dimitrijević, Poljoprivredni fakultet Univerziteta u Beogradu, Nemanjina ulica br. 6, 11080 Beograd, Telefon:+ 381642248 076, E-mail: bojandi@agrif.bg.ac.rs

9 Dr Dušan Milić, Poljoprivredni fakultet Univerziteta u Novom Sadu, Trg D. Obradovića br. 8, 21000 Novi Sad, Telefon: + 381635575 82, e-adresa: milic@polj.uns.ac.rs

10 Mr Zoran Milovančević, Kamenička 10, 34310 Topola, Telefon: + 381636477 83, E-mail: zoranmilovancevic@gmail.com 